\title{
Microstructural Observation of Silicon Nitride Ceramics Sintered with Addition of Titania
}

\author{
Toyohiko YANO, Junichi TATAMI,* Katsutoshi KOMEYA* and Takeshi MEGURO* \\ Research Laboratory for Nuclear Reactors, Tokyo Institute of Technology, 2-12-1, O-okayama, Meguro-ku, Tokyo 152-8550 \\ *Faculty of Engineering, Yokohama National University, 79-5, Tokiwadai, Hodogaya-ku, Yokohama-shi 240-8501
}

\author{
チタニア添加窒化ケイ素の微構造観察 \\ 矢野豊彦・多々見純一* ·米屋勝利* 目黒竹司 ${ }^{*}$ \\ 東京工業大学原子恼工学研究所, 152-8550 東京都目黒区大岡山 2-12-1 \\ *横浜国立大学工学部, 240-8501 横浜市保土ヶ谷区常盤台 79-5
}

\begin{abstract}
$\mathrm{Si}_{3} \mathrm{~N}_{4}$ sintered body was obtained by pressureless sintering and then post-HIPing with addition of small amount of $\mathrm{TiO}_{2}(3$ mass $\%)$. Sintering additives were 5 mass $\% \mathrm{Y}_{2} \mathrm{O}_{3}, 3$ mass $\% \mathrm{Al}_{2} \mathrm{O}_{3}$ and 3 mass $\% \mathrm{AlN}$. It was found that round-shaped particles with diameter $0.2-0.5 \mu \mathrm{m}$ were distributed within the grain-boundary phase. The particles contained high density crystalline imperfections. They contained $\mathrm{Ti}$ and $\mathrm{N}$, and were identified as TiN by energy-dispersive-type X-ray microanalysis and X-ray diffractometry. The grain-boundary phase was mainly an amorphous phase containing Si, $Y, A l$ and $\mathrm{O}$, but it did not contain Ti. Formation of TiN from $\mathrm{TiO}_{2}$ by reduction and nitridation was suggested based on thermodynamic calculations and crystal chemical considerations. High density crystalline imperfections may be introduced during reduction of $\mathrm{TiO}_{2}$ particles. It is believed that the grain-boundary distribution of round-shaped TiN particles contributes to the improvement of wear resistance of $\mathrm{Si}_{3} \mathrm{~N}_{4}$ ceramics.
\end{abstract}

[Received September 12, 2000; Accepted January 24, 2001]

Key-words : $\mathrm{Si}_{3} \mathrm{~N}_{4}$, TiN, TiO $\mathrm{T}_{2}$, Microstructure, Wear resistance, TEM, EDX

1. Introduction

Silicon nitride ceramics exhibit excellent strength, toughness and thermal shock resistance and has been highly developed for high-temperature structural applications such as gas turbine components and automobile engine parts such as turbo-charger rotor. It is also used as ceramic bearing parts and show excellent wear resistance under high-temperature or corrosive atmosphere. The mechanical properties of $\mathrm{Si}_{3} \mathrm{~N}_{4}$ or SiAlON ceramics influenced significantly by its microstructure, so that many microstructural investigations have been carried out, ${ }^{1-8)}$ particular attentions were paid on the development of $\beta-\mathrm{Si}_{3} \mathrm{~N}_{4}$ grain morphology, phase transformation, seeds particle effect or characterization of secondary phases.

It has been reported that the wear resistance property of $\mathrm{Si}_{3} \mathrm{~N}_{4}$ ceramics was improved by the addition of small amount of $\mathrm{TiO}_{2},{ }^{9}$ ) but the mechanism of the improvement of wear resistance was not clear. Then, in this report, microstructure of $\mathrm{Si}_{3} \mathrm{~N}_{4}$ sintered body with addition of $\mathrm{TiO}_{2}$ is examined mainly by transmission electron microscopy to clarify the effect of $\mathrm{TiO}_{2}$ addition, and then discuss the mechanism of wear resistance improvement. It is a merit for commercial production that a $\mathrm{TiO}_{2}$ powder is cheeper than a $\mathrm{TiN}$ powder.

\section{Experimental procedure}

Silicon nitride observed in this study was sintered at $1800^{\circ} \mathrm{C}$ under $0.1 \mathrm{MPa} \mathrm{N}_{2}$ gas atmosphere from the raw powder, SN-E10 of Ube with average particle size of $0.7 \mu \mathrm{m}$ in diameter. The sintered body was further hot-isostaticpressed at $1700^{\circ} \mathrm{C}$ for $1 \mathrm{~h}$ under $100 \mathrm{MPa} \mathrm{N}$. pressure. The following additives were mixed into the raw powder: 5 mass $\%$ of $\mathrm{Y}_{2} \mathrm{O}_{3}$ (RU, Shin-Etsu Chemical Co., Ltd.), 3 mass $\% \mathrm{Al}_{2} \mathrm{O}_{3}$ (AKP-30, Sumitomo Chemical Co., Ltd.) and 3 mass $\%$ AlN (Grade-F, Tokuyama, Average particle size of $0.6 \mu \mathrm{m}$ ). Furthermore, 3 mass $\%$ of $\mathrm{TiO}_{2}$ (Rutile type, R-11.P, Sakai Chemical, Average particle size of
$0.2 \mu \mathrm{m})$ was added. These powders were wet ball-milled. The obtained sintered bodies showed almost full density $\left(3.32 \mathrm{~g} / \mathrm{cm}^{3}\right)$.

Thin foils for transmission electron microscopy (TEM) were prepared by means of mechanical grinding, polishing, dimple-grinding and finally Ar ion-milling procedures. TEM used in the present study was an H-9000 (Hitachi) operating at $300 \mathrm{kV}$. A Kevex Delta-III energy-dispersive-type Xray microanalyzer equipped with an ultra-thin window was also used. Powder X-ray diffraction analysis was carried out using $\mathrm{Cu} \mathrm{K} \alpha$ radiation (Philips, $\mathrm{PW}-1100)$.

\section{Results}

Microstructure of the sintered body showed general feature of liquid-phase sintered $\mathrm{Si}_{3} \mathrm{~N}_{4}$, i.e., $\mathrm{Si}_{3} \mathrm{~N}_{4}$ grains with relatively large rod-like morphology (a few $\mu \mathrm{m}$ in long axis) and relatively small equi-axis grains (less than $0.5 \mu \mathrm{m}$ in diameter) surrounded by glassy grain-boundary phase. ${ }^{1), 5)}$ Grain-boundary glassy phase was recognized since they have sharp triangular edges with dark contrast, which was not changed by foil tilting. Relatively round-shaped particles with higher contrast were observed within the grain boundary phase throughout sintered body, as shown in Fig. 1. Slight higher magnification bright-field photograph, Fig. 1 (b), indicates that these particles contained very fine and high density irregular (not homogeneous) contrast. The size of these particles are 0.2 to $0.5 \mu \mathrm{m}$ and relatively constant. Furthermore, around the outer boundary of the particle, thin layer was sometimes observed as indicated by an arrowhead.

Figure 2 shows another particles in the sintered specimen. The contrast of round-shaped particles was resemble with those shown in Fig. 1. It is noted that one of the particles showed wavy contrast around outer part of the particle. Only the core part showed darker contrast. The outer part is more transparent than inner part and then looked as shadow of inner part. 

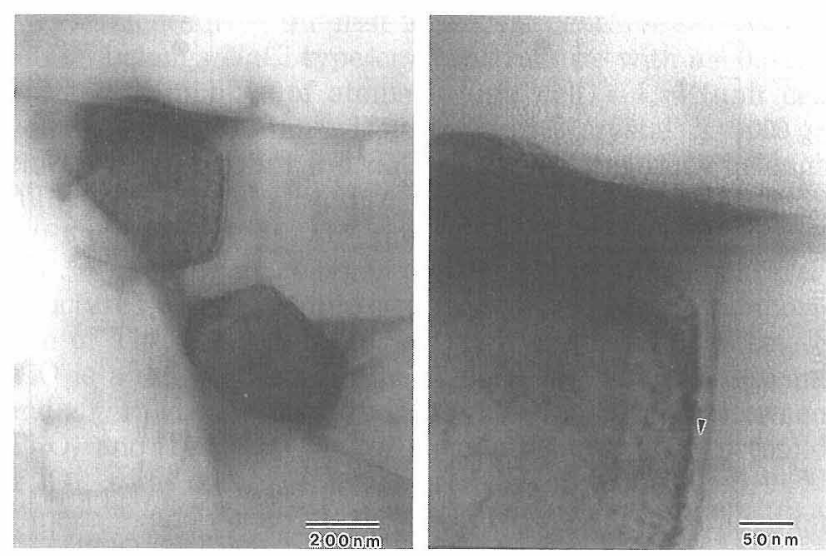

Fig. 1. (a) Bright-field micrograph of the specimen showing dark contrast particles. (b) An enlarged micrograph of a portion in (a). Outer layer-like contrast is indicated by an arrowhead.

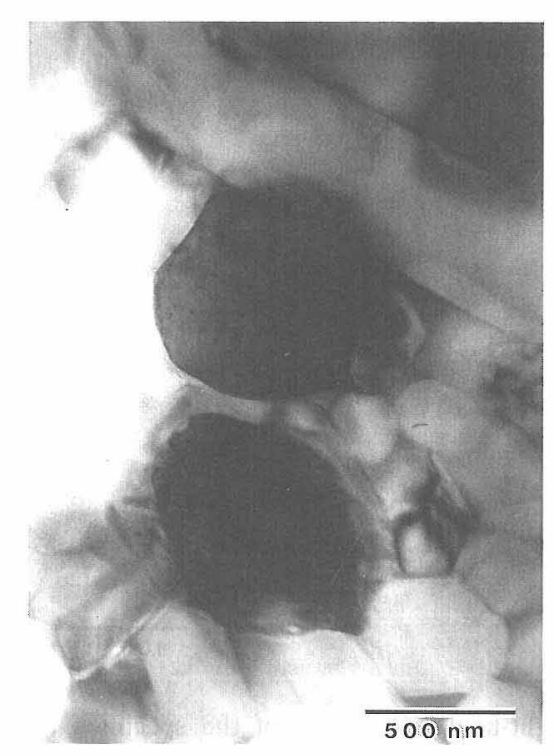

Fig. 2. Bright-field micrograph of the specimen. One of the particle showed wavy contrast around darker core.

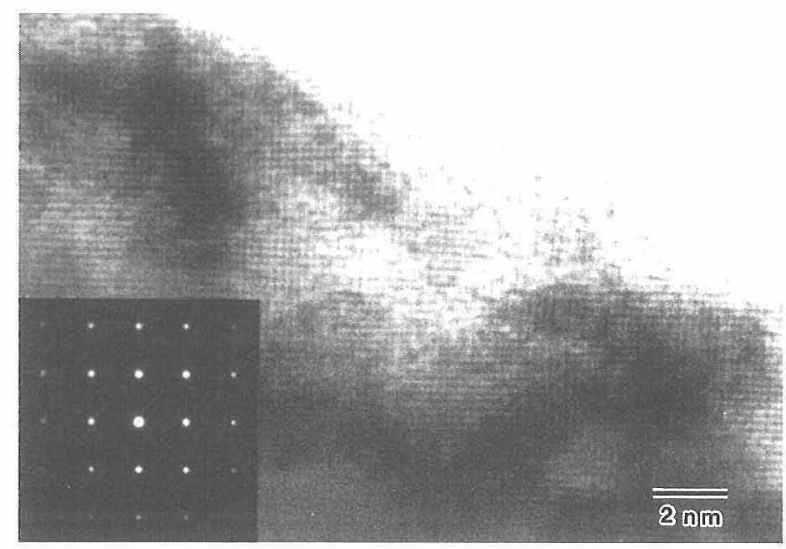

Fig. 3. High-resolution micrograph of darker-contrasted particle. Electron diffraction pattern of the particle is inserted.
Figure 3 is a high-resolution micrograph of darker-contrasted particle, of which diffraction pattern is inserted. The lattice fringes of the particle showed the array of dots crossing $90^{\circ}$. Distribution of darker contrast means the presence of some lattice irregularity such as dense dislocations. Shallow look of these array of dots clarifies that the arrays of dots are frequently curved or waved and presence of extra half-planes (dislocations). Analysis of the diffraction pattern indicated that it was consistent with the $\{100\}$ reciprocal plane of TiN.

EDX analysis was carried out for elongated grains, roundshaped grains and grain-boundary phase. The typical example of the results is shown in Fig. 4. Figure 4 (a) is a profile taken from an elongated grain, indicating that main constituents are $\mathrm{Si}$ and $\mathrm{N}$ (It is noted that intensity of light weight elements such as $\mathrm{O}, \mathrm{N}, \mathrm{C}$ is relatively very weak due to low detection efficiency of low energy characteristic Xrays), and a small amount of $\mathrm{Al}$ is also detected. This grain corresponds $\mathrm{Si}_{3} \mathrm{~N}_{4}$ or $\mathrm{SiAlON}$. It is well known that $\mathrm{Si}_{3} \mathrm{~N}_{4}$ is able to include $\mathrm{Al}$ and $\mathrm{O}$ which replace $\mathrm{Si}$ and $\mathrm{N}$, respectively, and making $\beta$-SiA1ON phase. ${ }^{10), 11)}$ The typical profile from small round-shaped particles with darker contrast is shown in Fig. 4(b). It is clear that the main constituents are $\mathrm{Ti}$ and $\mathrm{N}$. It is not clear that the trace amount of $\mathrm{Si}$ is the signal from the round-shaped grain or surrounding phases, but the latter case is more probable based on our experiences. The results strongly suggest that these particles are Ti-N phase. Grain-boundary was filled with almost glassy phase containing Si, Al, Y, O and N, as shown in Fig. 4(c). Ti was not contained in this phase. It was reported that the grain boundary phase was oxynitride glass when $\mathrm{Si}_{3} \mathrm{~N}_{4}$ was sintered with oxides such as $\mathrm{Al}_{2} \mathrm{O}_{3}$ and nitride such as AlN un-

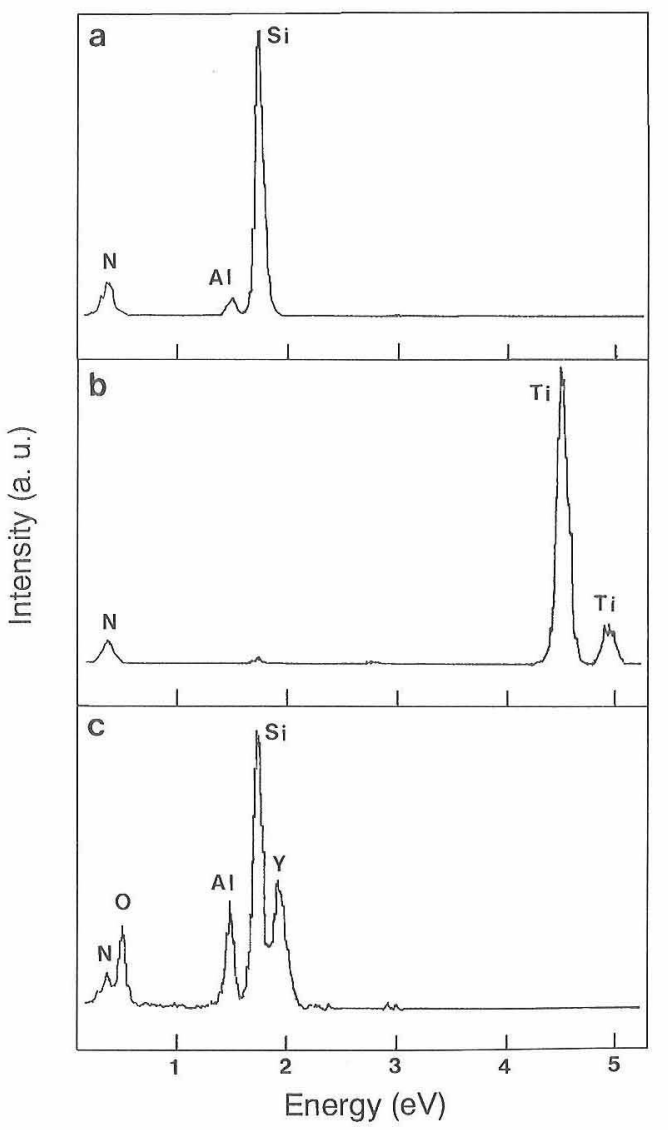

Fig. 4. EDX profiles of (a) elongated grains, (b) round-shaped grains and (c) grain-boundary phase. 
der $\mathrm{N}_{2}$ atmosphere. ${ }^{1), 2), 11), 12)}$ In the present specimen, it was concluded that the grain-boundary phase was mainly oxynitride glass.

Powder XRD profile indicated the presence of TiN as a minor phase with dominant $\beta-\mathrm{Si}_{3} \mathrm{~N}_{4}$ phase, as shown in Fig. 5. Very small unknown X-ray peaks with $d=0.3142$ and $0.2538 \mathrm{~nm}$ were detected, probably crystallized phase (s) in grain-boundary.

Round-shaped particles were observed for the same specimen before HIPing, and also confirmed as TiN by EDX analysis. These particles also contained high density crystalline imperfections, as shown in Fig. 6.

\section{Discussion}

Above mentioned experimental results clearly indicate that the round-shaped particles are TiN grains, and they distributed in grain-boundary phase throughout the sintered bodies. The size of these grains is almost corresponded to the size of raw $\mathrm{TiO}_{2}$ grains. TiN grains contained large amount of lattice strain and many crystalline imperfections. Sometimes the grains show a core-outer part double structure.

Hiraga et al. reported that TiN crystals in the $\mathrm{Si}_{3} \mathrm{~N}_{4}-\mathrm{TiN}$ composites prepared by chemical vapor deposition were very thin fiber-shaped and distributed in the matrix $\mathrm{Si}_{3} \mathrm{~N}_{4}$ crystal with specific crystallographic orientations. ${ }^{13)}$ The size and morphology of TiN particles in that report is quite different with those of the present study, because of different synthesis procedures. Iwamoto et al. recently reported that the synthesis of $\mathrm{Si}_{3} \mathrm{~N}_{4}$-TiN mixed powder by pyrolysis of polymer precursors. ${ }^{14}$ TiN particles obtained by this method was smaller than $100 \mathrm{~nm}$. There were several reports on $\mathrm{Si}_{3} \mathrm{~N}_{4}$-TiN system concerning mechanical properties, ${ }^{15)-17)}$ mechanical and electrical properties for electrical discharge machining, ${ }^{18)-22)}$ or porous sensor properties, ${ }^{23)}$ but these cases TiN powders were used as a raw material.

It is supposed that TiN grains in the present study were formed from $\mathrm{TiO}_{2}$. Possible reactions to form TiN are deduced based on the thermodynamic calculations, ${ }^{24)}$ as follows.

$$
\begin{aligned}
& 2 \mathrm{AlN}(\mathrm{s})+2 \mathrm{TiO}_{2}(\mathrm{~s}) \\
& \quad \longrightarrow 2 \mathrm{TiN}(\mathrm{s})+\mathrm{Al}_{2} \mathrm{O}_{3}(\mathrm{~s})+1 / 2 \mathrm{O}_{2}(\mathrm{~g}) \\
& \Delta G=\Delta G^{\circ}+1 / 2 R T \ln \left(P_{\mathrm{O}_{2}}\right)
\end{aligned}
$$

It is estimated that this reaction can proceed if the oxygen partial pressure is lower such as $5.9 \times 10^{-4}(\mathrm{~atm})$ at $1700 \mathrm{~K}$, $0.024(\mathrm{~atm})$ at $2000 \mathrm{~K}$ or $0.066(\mathrm{~atm})$ at $2100 \mathrm{~K}$. Another possible reaction is as follows.

$$
\begin{aligned}
& \mathrm{Si}_{3} \mathrm{~N}_{4}(\mathrm{~s})+4 \mathrm{TiO}_{2}(\mathrm{~s}) \\
& \quad 3 \mathrm{SiO}_{2}(\mathrm{l})+4 \mathrm{TiN}(\mathrm{s})+\mathrm{O}_{2}(\mathrm{~g}) \\
& \Delta G=\Delta G^{\circ}+R T \ln \left(P_{\mathrm{O}_{2}}\right)
\end{aligned}
$$

This reaction also can proceed if $P_{\mathrm{O}_{2}}<6.6 \times 10^{-7}$ (atm) at $1700 \mathrm{~K},<9.9 \times 10^{-6}(\mathrm{~atm})$ at $2000 \mathrm{~K}$ or $<3.85 \times 10^{-4}(\mathrm{~atm})$ at $2100 \mathrm{~K}$. Sintering of the present specimen was carried out at $2073 \mathrm{~K}\left(1800^{\circ} \mathrm{C}\right)$ under $0.1 \mathrm{MPa} \mathrm{N}_{2}$ atmosphere using carbon crucible and carbon heater furnace, therefore oxygen partial pressure should be much lower than these values required for both reactions, however, Reaction (1) occurs more easily. The amount of AIN ( 3 mass $\%$ ) to $\mathrm{TiO}_{2}$ (3 mass \%) is almost $2: 1$ in molar ratio in the present case, so sufficient amount of AIN is present. Thus, the rest of AIN may be dissolved into the glassy phase, which contains nitrogen as shown in Fig. 4(c).

Miyata et al. synthesized the $\mathrm{Si}_{3} \mathrm{~N}_{4}-\mathrm{TiN}$ composites with improved mechanical properties by nitridation of powder mixture of $\mathrm{Si}, \mathrm{TiC}$ and $\mathrm{TiO}_{2}$ and subsequent hot-pressing. They mentioned that $\mathrm{TiN}$ was formed from $\mathrm{TiC}$ and $\mathrm{TiO}_{2}$ by decomposition and nitridation during sintering, but trace of TiC particles was maintained in the composite. ${ }^{25)}$ Ueno et al. surveyed the "in-situ" formation of TiN grains into $\mathrm{Si}_{3} \mathrm{~N}_{4}$

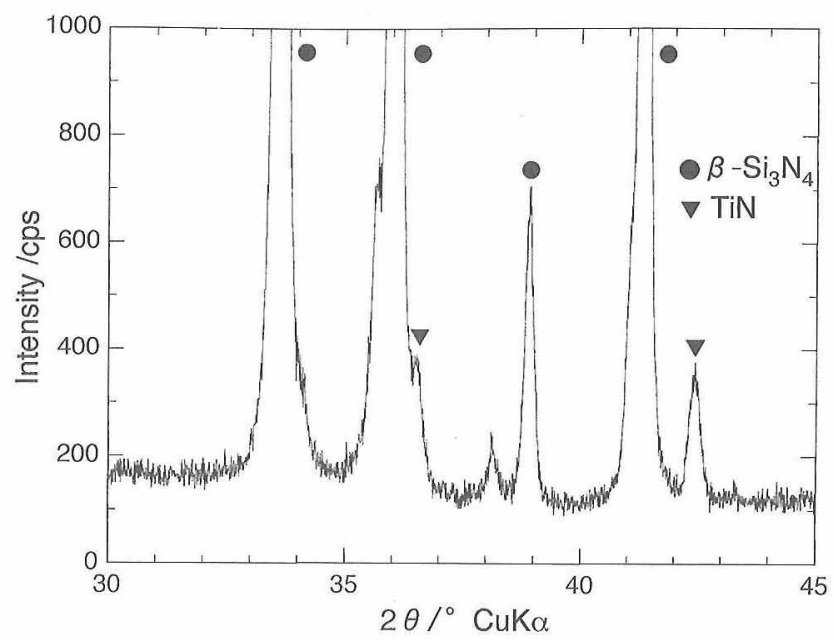

Fig. 5. XRD profile of the sintered specimen.

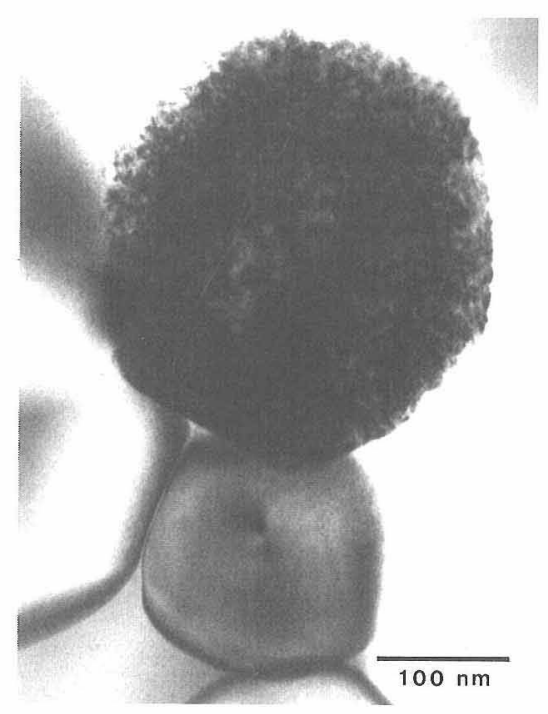

Fig. 6. Bright-field micrograph of the specimen before HIPing showing dark-contrasted particle.

matrix from the powder mixture of $\mathrm{TiO}_{2}$ and $\mathrm{AlN}$. ${ }^{26)}$ They confirmed the formation reaction of TiN through the Reaction (1) was progressed between 1150 to $1450^{\circ} \mathrm{C}$, before the $\mathrm{Si}_{3} \mathrm{~N}_{4}$ matrix sintering. Furthermore, if large particles $(>1$ $\mu \mathrm{m}$ ) of $\mathrm{TiO}_{2}$ were used as a raw material, it crumbled into fragments and underwent nitridation to TiN with a smaller size than that of the original particle. $\mathrm{TiN} / \mathrm{Si}_{3} \mathrm{~N}_{4}$ or $\mathrm{TiN} /$ $\mathrm{Si}_{2} \mathrm{~N}_{2} \mathrm{O}$ composites were also fabricated from powder mixture of $\mathrm{Si}, \mathrm{TiO}_{2}$ and additives after nitridation under $\mathrm{N}_{2}$ atmosphere. $\left.{ }^{27)}, 28\right)$ The former one case suggested that TiN was formed by nitridation of mainly $\mathrm{TiC}$ and the latter two cases from nitridation of $\mathrm{TiO}_{2}$ particles. Yoshimura et al., ${ }^{29)}$ $\mathrm{Umezu}^{30)}$ and Licko et al. ${ }^{31)}$ also reported TiN particles formation from $\mathrm{TiO}_{2}$ and $\mathrm{C}$ mixture under $\mathrm{N}_{2}$ atmosphere. Since present system of the raw mixture is the same as that of Ueno et al., and based on the many reports mentioned above, it is certain that $\mathrm{TiN}$ is produced from $\mathrm{TiO}_{2}$, but further microstructural and crystallo-chemical analyses are seemed to be important. These round-shaped particles were observed for the same specimen before HIPing, and also confirmed as TiN by EDX analysis. It is indicated that TiN 
was formed during the first heat treatment.

TiN belongs $\mathrm{NaCl}$ type crystal structure with $a=0.4239$ $\mathrm{nm}$ and $Z$ (number of atoms in unit cell) $=4, V$ (unit cell volume $)=0.07617 \mathrm{~nm}^{3}$. Density of the crystal is $5.43 \mathrm{~g} /$ $\mathrm{cm}^{3}{ }^{32)}$ On the other hand, $\mathrm{TiO}_{2}$ of the present study belongs rutile type crystal structure with $a=0.4592 \mathrm{~nm}, c=0.2959$ $\mathrm{nm}$ and $Z=2, V=0.0624 \mathrm{~nm}^{3}$. Density of $\mathrm{TiO}_{2}$ is $4.26 \mathrm{~g} /$ $\mathrm{cm}^{3}{ }^{32}$ ) There are oxygen-deficient structures (sheared structure) based on rutile structure with chemical composition of $\mathrm{Ti}_{n} \mathrm{O}_{2 n-1}(n=4-10)$. ${ }^{33)}$ High temperature phase of $\mathrm{TiO}$ is a defected $\mathrm{NaCl}$ type structure with $a=0.4180 \mathrm{~nm}$ and $Z=4, V=0.0730 \mathrm{~nm}^{3}$. Density is $4.93 \mathrm{~g} / \mathrm{cm}^{3}$. Between $\mathrm{Ti}_{4} \mathrm{O}_{7}$ and $\mathrm{TiO}, \mathrm{Ti}_{3} \mathrm{O}_{4}$ with pseudobrookite structure and $\mathrm{Ti}_{2} \mathrm{O}_{3}$ with corundum type structure are existed. ${ }^{33), 34)}$ $\mathrm{Umezu}^{30)}$ and Licko et al. ${ }^{31)}$ indicated that the transition from $\mathrm{TiO}_{2}$ to $\mathrm{TiN}$ happened via "lower oxides" such as $\mathrm{Ti}_{4} \mathrm{O}_{7}, \mathrm{Ti}_{2} \mathrm{O}_{3}$ or $\mathrm{TiO}$. Based on these reports and these crystal chemical data of crystals, the following changes in crystal structure was expected. First, $\mathrm{TiO}_{2}$ with rutile type structure gradually changes it composition due to pull out of oxygen with keeping basically rutile-type structure (shared structures (and pseudobrookite structure)). Further reduction of oxygen necessitates reconstructive structural changes into corundum type or $\mathrm{NaCl}$ type structures, if the composition changed gradually and there is sufficient time to reconstruct these structures. It is supposed that reduction and nitridation reaction from the phase of basically rutile type structures will simultaneously happen, ${ }^{31)}$ instead of the formation of $\mathrm{NaCl}$ type $\mathrm{TiO}$ and subsequent nitridation to $\mathrm{TiN}$, if the reaction happened very quickly under higher temperature-increasing rate. As a result, crystalline imperfections originally induced into the sheared structures are possibly included into TiN crystals. This seems to be the reason of high defect density in TiN particles, resulting darker contrast due to lattice strain, as shown in Figs. 1-3 and 5 . Change from $\mathrm{TiO}_{2}$ to $\mathrm{TiN}$ induces volume shrinkage of about $40 \%$ and corresponding density increase of $27 \%$ for the same number of Ti atom.

Further interest feature of TiN grains observed in Figs. 1 (b) and 2 is shadow-like contrast surrounding a roundshaped core part of some particles. Core part of the shadowlike contrast was TiN in the present study, and this feature seemed to be formed by the effects of surrounding liquidus phase during phase transition, since TiN formed from $\mathrm{TiO}_{2}$ without liquidus phase maintained its original irregular shape ${ }^{28)}$ and $\mathrm{TiN}$ formed from $\mathrm{TiO}_{2}$ was covered with carbon layer maintaining original particle shape. ${ }^{31)}$ If $\mathrm{TiN}$ phase is obtained from the center core of the particles, this is an experimental result, it will be formed into relatively round-shape morphology and an excess volume is rest around particles due to large volume shrinkage, consequently further filling up of glassy phase is expected. Since it is a non-crystalline phase, it looks more homogeneous without crystalline defects. It may lead shadow-like contrast. Ueno et al. reported that the nitridation reaction of $\mathrm{TiO}_{2}$ was completed as low temperature as $1450^{\circ} \mathrm{C}$. ${ }^{26}$ ) But under actual sintering condition, reduction-nitridation process and glassy phase formation may overlapped during increasing specimen temperature. From microstructure observation, voids or pores were not observed around TiN particles. It is considered that the evolved $\mathrm{O}_{2}$ gas due to the Reaction (1) was used as oxidant of $\mathrm{AlN}$ or $\mathrm{Si}_{3} \mathrm{~N}_{4}$, or dissolved into grainboundary phase. Schematic illustration of a sequence of reaction is presented in Fig. 7.

\section{$\mathrm{Ti}_{\mathrm{n}} \mathrm{O}_{2 \mathrm{n}-1}($ sheared structure $)$}

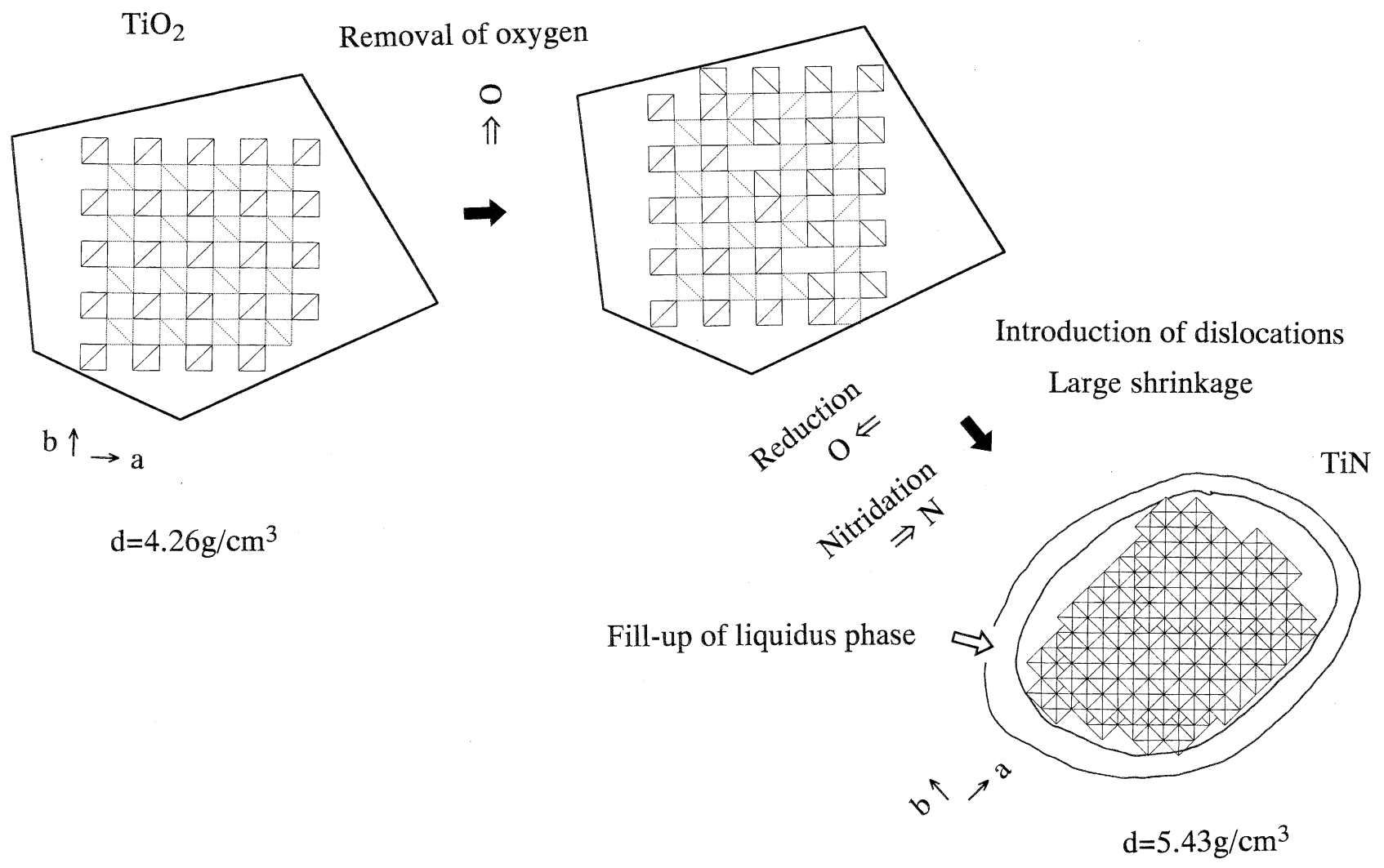

Fig. 7. Schematic illustration of a sequence of reactions. 
It has been reported that the wear resistance property has been improved by the addition of small amount of $\mathrm{TiO}_{2}$. Hayashi et al. $\left.{ }^{9}\right)$ reported that the bending strength of the $\mathrm{Si}_{3} \mathrm{~N}_{4}$ specimen containing TiN after $10^{5}$ cyclic indentation test using $\mathrm{WC} / \mathrm{Co}$ ball did not change, comparing large decrease of bending strength in the specimen without TiN. Improvement of wear resistance can be partly explained by the formation of TiN grains, since Vickers hardness of TiN $(25 \mathrm{GPa})$ is higher than that of a liquid-phase sintered $\mathrm{Si}_{3} \mathrm{~N}_{4}$ (15-18 GPa). Furthermore, Reaction of (1) produces $\mathrm{Al}_{2} \mathrm{O}_{3}$, which is a constituent of a liquid phase, therefore increase in sinterability may be attained due to increase in $\mathrm{Al}_{2} \mathrm{O}_{3}$. From the view point of wear resistance, distribution of round-shaped TiN within grain-boundary phase has some merits such as difficulty to grain falling-out. Formation of TiN grains from $\mathrm{TiO}_{2}$ grains does not induces internal tensile strain into surrounding matrix, since large volume shrinkage is expected.

\section{Conclusions}

$\mathrm{Si}_{3} \mathrm{~N}_{4}$ sintered body was obtained by pressureless sintering and then HIPping with addition of small amount of $\mathrm{TiO}_{2}$ $(3$ mass $\%)$. Sintering additives were 5 mass $\% \mathrm{Y}_{2} \mathrm{O}_{3}, 3$ mass $\% \mathrm{Al}_{2} \mathrm{O}_{3}$ and 3 mass $\% \mathrm{AlN}$. It was found that roundshaped particles with $0.2-0.5 \mu \mathrm{m}$ in diameter distributed in grain-boundary phase throughout sintered body. These particles showed dark contrast during electron microscopy due to the presence of high density crystalline imperfections. Furthermore, sometimes they showed shadow-like contrast surrounding a core part. This particle contained Ti and N, and was identified as TiN based on EDX analysis and XRD. Formation of TiN from $\mathrm{TiO}_{2}$ by reduction and nitridation was suggested based on thermodynamic calculations and crystal chemical considerations. High density crystalline imperfections may be introduced during reduction of $\mathrm{TiO}_{2}$ particles into the lower oxides. It is believed that the distribution of round-shaped TiN particles contributes the improvement of the wear resistance of $\mathrm{Si}_{3} \mathrm{~N}_{4}$ ceramics.

Acknowledgements The work was partly supported by JSPS Research for the Future Program, and a Grant-in-Aid for Scientific Research from the Ministry of Education, Science, Sports and Culture.

\section{References}

1) Kleebe, H. J., J. Ceram. Soc. Japan, 105, 453-75 (1997).

2) Hwang, S.-L. and Chen, I. W., J. Am. Ceram. Soc., 77, 1719-28 (1994)

3) Lee, W. E. and Hilmas, G. E., J. Am. Ceram. Soc., 72, 1931-37 (1989)

4) Hirosaki, N., Tanimura, M., Okamoto, Y., Akimune, Y. and Mitomo, M., J. Ceram. Soc. Japan, 102, 875-79 (1994) [in Japanese].

5) Hirosaki, N., Okamoto, Y., Akimune, Y. and Mitomo, M., J. Ceram. Soc. Japan, 102, 790-94 (1994) [in Japanese].

6) Hirosaki, N. and Matsubara, H., J. Ceram. Soc. Japan, 105, 218-22 (1997) [in Japanese].
7) Imamura, H., Hirao, K., Brito, M. E., Toriyama, M. and Kanzaki, S., J. Ceram. Soc. Japan, 104, 748-51 (1996) [in Japanese].

8) Akimune, Y., Munakata, F., Matsuo, K., Okamoto, Y., Hirosaki, N. and Sato, C., J. Ceram. Soc. Japan, 107, 1180-82 (1999).

9) Hayashi, T., Tatami, J., Komeya, K., Meguro, T. and Kim, D.-K., Proc. 19th Forum on Basic Science for High-Temperature Ceramics (2000) pp. 25-27 [in Japanese].

10) Oyama, Y. and Kamigaito, O., Japan. J. Appl. Phys., 10, 1637 (1971).

11) Jack, K. H., J. Mater. Sci., 11, 1135-58 (1976).

12) Ukyo, Y. and Suda, A., J. Ceram. Soc. Japan, 104, 371-76 (1996).

13) Hiraga, K., Hirabayashi, M., Hayashi, S. and Hirai, T., J. Am. Ceram. Soc., 66, 539-42 (1983).

14) Iwamoto, Y., Kikuta, K. and Hirano, S., J. Ceram. Soc. Japan, 108, 350-56 (2000).

15) Nagaoka, T., Yasuoka, M., Hirao, K. and Kanzaki, S., J. Ceram. Soc. Japan, 100, 617-20 (1992).

16) Sato, Y. and Ueki, M., J. Ceram. Soc. Japan, 101, 365-68 (1993) [in Japanese].

17) Herrmann, M., Balzer, B., Schubert, C. and Hermel, W., J. Eur. Ceram., 12, 287-96 (1993).

18) Akimune, Y., Munakata, F., Ando, M., Okamoto, Y. and Hirosaki, N., J. Ceram. Soc. Japan, 105, 122-25 (1997) [in Japanese].

19) Akimune, Y., Munakata, F., Hirosaki, N. and Okamoto, Y., J. Ceram. Soc. Japan, 106, 75-78 (1998) [in Japanese].

20) Sinha, S. N. and Tiegs, T. N., Ceram. Eng. Sci. Proc., 16, 489-96 (1995).

21) Yasutomi, Y. and Sobue, M., Ceram. Eng. Sci. Proc., 11, 857-67 (1990).

22) Bellosi, A., Guicciardi, S. and Tampieri, A., J. Eur. Ceram., 9, 83-93 (1992).

23) Nakayama, S. and Kuroshima, H., J. Ceram. Soc. Japan, 100, 758-62 (1992) [in Japanese].

24) JANAF Thermodynamic Tables, 3rd ed., J. Phys. Chem., Ref. Data, 14 [Suppl. 1] (1985).

25) Miyata, M., Yasutomi, Y., Sawai, Y. and Kanai, T., J. Ceram. Soc. Japan, 105, 761-67 (1997) [in Japanese].

26) Ueno, K., Inoue, T., Sodeoka, S., Suzuki, M., Ishikawa, H., Uchiyama, K. and Inui, T., J. Ceram. Soc. Japan, 105, 304-07 (1997).

27) Shih, C. J., Yang, J.-M. and Ezis, A., Scripta Metal. Mater., 24, 2419-24 (1990).

28) Liu, W., Yang, J.-M., Ting, S.-J., Ezis, A. and Shih, C. J., J. Am. Ceram. Soc., 75, 2945-52 (1992).

29) Yoshimura, M., Nishioka, M. and Sōmiya, S., J. Mater. Sci. Lett., 6, 1463-65 (1987).

30) Umezu, S., Proc. Imperial Acad., 7, 353-56 (1931).

31) Licko, T., Figusch, V. and Puchyova, J., J. Eur. Ceram., 5, 257-65 (1989).

32) Pearson's Handbook of Crystallographic Data for Intermetallic Phases, Ed by Villars, P. and Calvert, L. D., American Metal Society Press, Metal Park, OH (1985).

33) Fueki, K. and Yamauchi, S., "Kagaku-Sousetsu," Vol. 9, Ed by Chemical Society of Japan, University of Tokyo Press (1975) pp. 7-30 [in Japanese].

34) Kiriyama, R. and Kiriyama, H., "Kouzou-Muki-Kagaku, I," Kyoritsu Shuppan, Tokyo (1964) [in Japanese]. 